\section{Production of Yeast Cells from Methanol}

\section{Haruya TezuKa, * Tadaatsu NaKaHARA, Yasuji MINODA and Koichi Yamada}

\author{
Department of Agricultural Chemistry, \\ Faculty of Agriculture, The University \\ of Tokyo ,Tokyo
}

Received July 29, 1974

In recent years, many studies on yeast cell production from methanol have been reported. ${ }^{1 \sim 4}$ ) The present authors isolated newly several methanolutilizing yeasts from natural sources and selected one strain from them based on growth rate and cell yield. This paper deals with isolation and identification of methanol-utilizing yeast, some cultural conditions and the components of the cell.

To isolate methanol-utilizing yeasts from natural sources, soil or natural materials were added in the large test tube containing the isolation medium and were shaken for four or seven days at $30^{\circ} \mathrm{C}$. The isolation medium contained $10 \mathrm{~g}$ methanol, $3 \mathrm{~g}\left(\mathrm{NH}_{4}\right)_{2}-$ $\mathrm{SO}_{4}, 2 \mathrm{~g} \mathrm{KH}_{2} \mathrm{PO}_{4}, 0.4 \mathrm{~g} \mathrm{MgSO}_{4} \cdot 7 \mathrm{H}_{2} \mathrm{O}, 0.01 \mathrm{~g} \mathrm{FeSO}_{4}$. $7 \mathrm{H}_{2} \mathrm{O}, 0.01 \mathrm{~g} \mathrm{CaCl}_{2} \cdot 2 \mathrm{H}_{2} \mathrm{O}, 50 \gamma$ biotin, $500 \gamma$ thiamine$\mathrm{HCl}, 1 \mathrm{~g}$ yeast extract and $0.3 \mathrm{~g}$ streptomycin in $1000 \mathrm{ml}$ tap water ( $\mathrm{pH}$ 5.5). The enrichment culture was repeated four times. Then, $0.1 \mathrm{ml}$ of the shaken media was spread on agar plates containing the isolation medium to form yeast colonies.

For the test of cell production, $5 \mathrm{ml}$ seed culture broth was transferred into $50 \mathrm{ml}$ of the medium in a $500 \mathrm{ml}$ shaking flask and incubated for 24 to $60 \mathrm{hr}$ at $30^{\circ} \mathrm{C}$ on reciprocal shaker. Cell growth was determined by measuring optical density at $660 \mathrm{~nm}$ and weighing dried cells.

Residual methanol concentration was analyzed by gas-liquid chromatography under the following conditions: column, PEG $10003 \mathrm{~mm} \times 1 \mathrm{~m}$ of stainless steel; temperature, isothermal at $100^{\circ} \mathrm{C}$; carrier gas, helium; carrier gas flow rate, $40 \mathrm{ml} / \mathrm{min}$; detector, TCD; injection, $5 \mu 1$ of broth; and equipment, Shimazu Gas Chromatography GC-3AH.

Thirty-two strains were isolated from about 1500 samles of natural materials, such as soil, sewage and rind of fruit. Eight strains showed good growth on methanol. The most excellent utilizer was selected from three strains having high growth rate and cell yield by batch culture using jar fermenter. Operation conditions of jar fermenter were as follows, working volume, 16 liters; cultural temperature, $30^{\circ} \mathrm{C}$; aeration, 16 liters/min; agitation speed, $400 \mathrm{rpm} ; \mathrm{pH}, 5.5$; inoculum size, $500 \mathrm{ml}$ of seed culture and cultivation time, $40 \mathrm{hr}$. $\mathrm{pH}$ was adjusted by adding $\mathrm{NH}_{4} \mathrm{OH}$.

Table I indicates that strain F433 is inferior to other strains, F432 and S773. Although F432 showed growth as well as $\mathrm{S} 773$ in this experiment, S773 was selected as the most excellent strain, considering the result of the experiment using $500 \mathrm{ml}$ shaking flask. It was found that more than $20 \%$ of fed methanol escaped in vapor when initial methanol concentration was $1 \%(w / w)$. But when its concentration was $0.5 \%$, lost methanol decreased considerably.

Maximum cell yield was obtained under the following conditions, cultivation temperature, $26.5^{\circ} \mathrm{C} ; \mathrm{pH}$, $4 \sim 6$; methanol concentration, $0.5 \%$ (w/w); corn steep liquor concentration, $2 \mathrm{~g} /$ liter; nitrogen sources, $3 \mathrm{~g}$ $\left(\mathrm{NH}_{4}\right)_{2} \mathrm{SO}_{4}$. Maximum cell yield and specific growth rate were $49.5 \%(\mathrm{w} / \mathrm{w})$ and $0.2 \mathrm{hr}^{-1}$, respectively.

Strain $\mathrm{S} 773$ could not grow on methanol at the concentration more than $3 \%$ and its cell yield to fed methanol increased with decreasing of methanol concentration. This strain required natural nutrients for the growth. The sufficient amount of yeast extract, corn steep liquor and whisky soluble for the maximum growth of the strain were $1 \mathrm{~g} /$ liter, $2 \mathrm{~g} /$ liter and $2 \mathrm{~g} /$ liter, respectively.

The typical time course showing growth and methanol consumption under $\mathrm{pH} 5.5$ is presented in Fig. 1. Exponential growth was observed through cultivation when initial concentration was $0.5 \%$.

When yeast is used as feed or food suppiement, it

Table I. Selection Test of Yeast for Cell Production By Batch Culture with Jar Fermenter

\begin{tabular}{|c|c|c|c|c|c|}
\hline \multicolumn{2}{|l|}{ Strain No. } & \multirow{2}{*}{$\frac{S 773}{157}$} & \multirow{2}{*}{$\frac{S 773}{79}$} & \multirow{2}{*}{$\frac{F 432}{157}$} & \multirow{2}{*}{$\frac{F 433}{157}$} \\
\hline Fed methanol & (g) & & & & \\
\hline Recovered methanol & (g) & 36 & 10 & 37 & 34 \\
\hline Consumed methanol & (g) & 121 & 69 & 120 & 123 \\
\hline Cell dry weight & (g) & 47 & 31 & 41 & 46 \\
\hline Cell yield & $(w t \%)$ & 39 & 45 & 34 & 35 \\
\hline Specific growth rate & $\left(h r^{-1}\right)$ & 0.14 & 0.2 & 0.15 & 0.11 \\
\hline
\end{tabular}

* Present address: Shinetsu Chemical Industry Co., Ltd. 


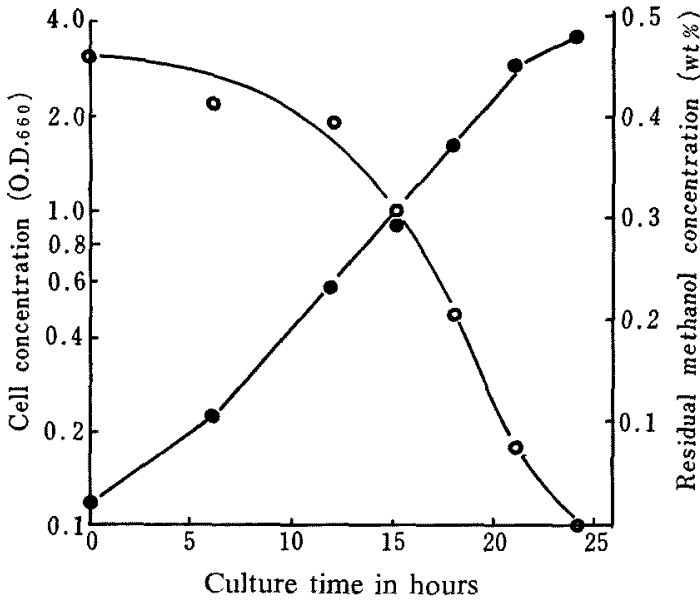

Fra. 1. Typical Growth Curve of Strain S773.

- Cell concentration.

$\mathrm{O}-\mathrm{O}$, Residual methanol concentration.

is desired for yeast cell to have not only high cell yield and growth rate but also high protein content and low RNA content. Crude protein and RNA contents were determined by semimicro-Kjeldahl method and Schmidt-Thanhauser-Schneider method, respectively. The crude protein and RNA contents in strain S773 were $45.7 \%$ and $3.4 \%$, respectively. The former was as much as other methanol yeasts and hydrocarbon yeasts, however, the latter was less than Kloeckera sp. reported by Ogata et al. ${ }^{11}$ and strain DL-1 reported by Levine and Cooney.4)

As strain $\mathrm{S773}$ was comparatively excellent as single cell protein producer, taxonomical studies of the strain were carried out. From the results of morphological and physiological studies, it was identified as close resembling Candida boidinii, as shown in Table II. But it differed from Candida boidinii in the following points, 1) Succinic acid was utilized but dl-lactic acid was not. 2) Maximum temperature of the growth was $40^{\circ} \mathrm{C}$.
Table II. Taxonomical Studies of STRAIN S773

Growth in malt extract broth: After two days at $25^{\circ} \mathrm{C}$, cells were long ovoid to cylindrical $(3.0 \sim 5.0) \times(6.0 \sim 10.0) \mu$, isolated or in pairs.

Growth on malt extract agar: After two days at $25^{\circ} \mathrm{C}$, colonies were white colored, raised and smooth.

Ascospore formation: negative

Ballistospore formation: negative

Pseudo-true mycelium formation: positive

Fermentation:

Glucose

Galactose, Maltose, Lactose,

Raffinose, Trehalose

positive

Assimilation of carbon compound:

negative

Glucose, Mannose, Fructose, Xylose, Mannitol, Dextrin, Glycerin, Ethanol, Succinic acid

positive

Galactose, Lactose, Maltose, Raffinose, Sucrose, Trehalose, Methyl glucoside, Mellibiose, Arabinose, Soluble starch, Inulin, Salicin, $d l$-Lactic acid, Citric acid

negative

\section{REFERENCES}

1) K. Ogata, H. Nishikawa, M. Ohsugi and $T$. Tochikura, J. Ferment. Technol., 48, 389 (1970).

2) H. Asthana, A. E. Humphrey and V. Moritz, Biotechnol. Bioeng., 13, 923 (1972).

3) T. Oki, K. Kouno, A. Kitai and A. Ozaki, J. Gen. Appl. Microbiol., 18, 295 (1972).

4) D. W. Levine and C. L. Cooney, Appl. Microbiol., 26, 982 (1973).

5) “The Yeast, a taxonomic study," ed. by J.Lodder, North-Holland Publishing Co. Amsterdam. London, 1970, p. 929. 